Annals of Warsaw University of Life Sciences - SGGW

Land Reclamation No 42 (2), 2010: 271-278

(Ann. Warsaw Univ. of Life Sci. - SGGW, Land Reclam. 42 (2), 2010)

\title{
Protection of valuable water dependent ecosystems in urban areas
}

\author{
DARIA SIKORSKA ${ }^{1}$, PIOTR SIKORSKI ${ }^{2}$, PIOTR HEWELKE ${ }^{1}$ \\ ${ }^{1}$ Department of Environment Improvement, Warsaw University of Life Sciences - SGGW \\ ${ }^{2}$ Department of Environmental Protection, Warsaw University of Life Sciences - SGGW
}

\begin{abstract}
Protection of valuable water dependent ecosystems in urban areas. Water dependent ecosystems are habitats most vulnerable to urbanization pressure. There are not many such habitats in Warsaw. Those which remained are mostly dewatered sites existing within green areas such as parks. Habitats with peat and moorsh soils have a unique value, thus there is a rational need for detailed research and evaluation to preserve them. This paper is a case-study of two different water dependent ecosystems, localized within the boundaries of Poland's capital city, both remaining under strong urbanization pressure. Different actions were undertaken to preserve those habitats, with differing results. We examined tendencies of vegetation during recent 20-30 years, basing on floristical data. In the areas, where water regime has been disrupted, like Natural Landscape Complex "Olszyna" a significant decline of plants rare in the scale of Warsaw is being noticed. Habitats not disturbed by human interference like "Zakole Wawerskie" do not suffer significant changes, even an increase of rare plants was marked. Presence of water dependent ecosystems is also correlated with population density. In the areas of highest population density these habitats occur seldom, are of a small size and have simplified border zones. The only areas within Warsaw borders where water dependent ecosystems maintained are the urban parks. In the last decades a progressive decline of wetlands is being noticed, which was also confirmed in this study. The only real chance for further preservation of this areas is to create biodiversity hotspots and good recreation infrastructure.
\end{abstract}

Key words: water dependent ecosystems, urbanization, vegetation changes, protected areas.

\section{INTRODUCTION}

Over half of world's population lives in urban areas, in Poland this problem concerns over $61 \%$ of people (Statistical Yearbook of Poland 2010) and this number keeps rising. Thus urban landscapes have a significant effect on most humans' life quality. A typical feature of city landscapes is presence of artificial constructions with increased number of impermeable surfaces, high population density, presence of non-native plant and animal species but also disturbed circulation of energy and matter. (McDonnell, Pickett 1997; Sukopp 1998; McKinney 2002). Areas of cities are generally more destroyed then rural areas (Ehrenfeld 2000; Baldwin 2004). Progressing urbanization, especially in big cities affects structure and functioning of natural ecosystems (Grime et al. 2000). The effect of urban-industrial surrounding on the type and rate of such disturbances is poorly understood mainly because of only a few objects studied (Symonides and Solińska-Górnicka 1990). Transformation of vegetation is best visible in hydrogenic soils whose physical properties are affected by the regulation of water 
relations. Proceeding drainage caused by both natural factors and human impact leads to the transformation of plant communities (Kloss 2001). Substitute plant communities are being formed as a result of intensive drainage.

This study was undertaken to assess changes of vegetation in two different water dependant habitats localized in Warsaw. We examined occurrence of plant species which are protected or partially protected according to Polish law, and other valuable species, which are characteristic for rare plant communities.

\section{STUDY AREA}

Two similar wetlands were selected in Warsaw, both suffering from strong urbanization, remaining under protection as Natural Landscape Complexes (Fig. 1). Natural Landscape Complex "Olszyna" is located in the north-western part of Warsaw. It consists of 2.23 ha and is mostly covered by alder woodland. In the research area an unconfined water table is situated under peat layer (Pajnowska et al. 1996). Alder-ash riparian communities, locally dried out into low dry ground forests, have been preserved there. Development of road infrastructure and building of an artery in its closest neighborhood resulted in the decline of ground water table and in limited infiltration of rainfall waters. In the 1970's actions were undertaken to protect "Olszyna" through building reservoirs and open ditches which keep the water level elevated. This however didn't allow spring flooding which occurred in this area before. Despite protective mea-

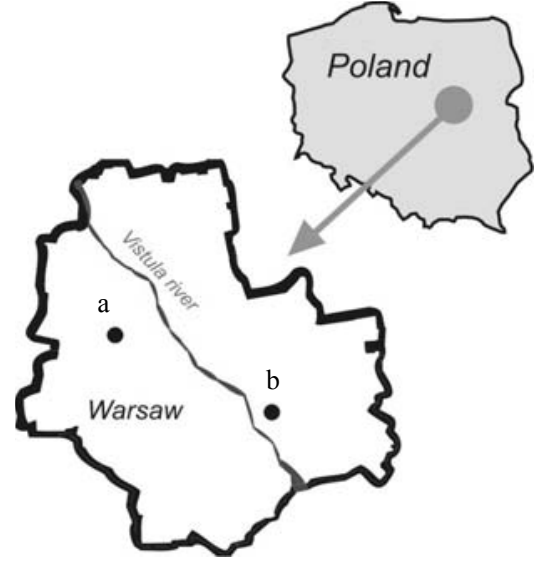

FIGURE 1. Localization of research areas; a Natural Landscape Complex "Olszyna", b - Natural Landscape Complex "Zakole Wawerskie"

sures, marked changes in plant communities took place.

Natural Landscape Complex "Zakole Wawerskie" is localized in Eastern Warsaw and consists of 55 ha. It is covered by a mosaic of wet meadows and riparian forests. Similarly to "Olszyna" a main artery was built in its neighborhood, but water relations for now remain unchanged.

\section{MATERIAL AND METHODS}

In this study total area of water dependent ecosystems in Warsaw was calculated. This includes landscapes of river valleys, swamp plains, peatlands and lakes, landscapes of river deltas. To asses distribution of this type of ecosystems we used soil map (Anonymous 2002) and elaboration by Pawlak and Kaliszuk (2006) for assessment of green areas in Warsaw. Population rates and areas of districts were used according to Central Statistical Office of Poland (GUS 2008). 
To asses level of habitat fragmentation we calculated landscape metrics (McGarigal and Marks 1994, Roo-Zielińska et al. 2007) using Geographical Information Systems software - ArcGIS and Patch Analyst plugin. We calculated: number of patches of water dependent ecosystems, their total and mean area, length of edges, density of edges. Significance of correlation coefficient between population number and habitat fragmentation was then calculated using STATISTICA 8 software.

In both study areas representative plots were selected where floristical data was collected. In "Olszyna" plant species were firstly listed in the 1973 by Wysocki, short after the building of a main route in the adjacent area, when also artificial system of ditches and pumps was created to keep the water table elevated (Pajnowska et al. 1996). Second recording of plants was performed in 2008, over 20 years after the investment. In case of "Zakole Wawerskie" a detailed survey concerning plant species was held firstly in 1991, then in 2008 we searched again for the rare species listed earlier. In both cases inventory was held both in spring and summer. We recorded valuable plant species, which are either protected or partially protected by Polish law or are characteristic plants of rare plant communities. Rare species included in this study were selected using 3 criteria (Gauthier et al. 2010) representativeness of the region (Warsaw city), rareness within the selected region, habitat fragility. The first 2 criteria were assessed on the basis of species distribution maps (Sudnik-Wójcikowska 1987a, 1987b), fragility was assessed using indi- cator values for moisture and resistance to drought (Ellenberg et al. 1991).

\section{RESULTS}

Water dependent ecosystems decrease their area proportionally to urbanization pressure. In central administrative units, where population density is the highest, we observed the smallest area of investigated habitats, smallest number of patches, but also, smallest length of border zones, which are of a great importance to many animals and plant species (Tabs 1 and 2). Overlying maps of localization of water dependent habitats and maps of green areas, managed by city authorities, indicates that in the centre of the city the only locations, where wetlands were preserved, are the urban parks (Fig. 2).

Floristical analysis of objects, where big road infrastructure was built in the neighborhood, reveals differing results of the investments on this ecosystems. In case of "Zakole Wawerskie" where little disturbance of water relations occurred, rare plant species did not extinct. On the other hand in "Olszyna" where groundwater level decreased significantly and system of irrigation ditches was created, number of rare species surprisingly increased, which means they must have appeared between 1973 and 2007 (Tab. 3). This is because former habitats of "Olszyna" had already been poor in rare species before investment, those which have recently appeared are connected with mesophilous forests, their presence is more connected with lack of spring flooding and lower soil moisture content. 


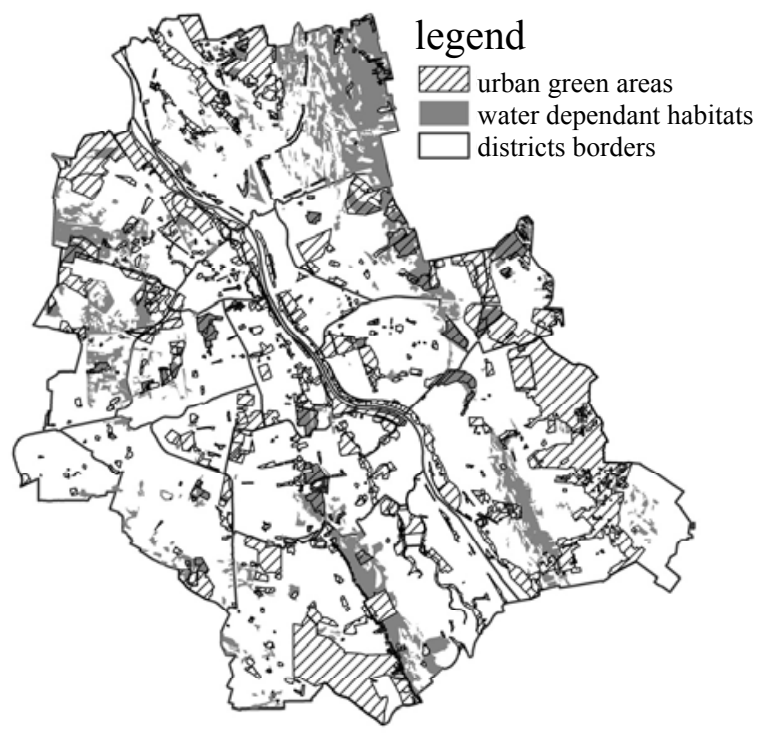

FIGURE 2. Water dependent habitats and green areas of Warsaw (on the basis of Pawlak and Kaliszuk 2006)

TABLE 1. Population [number of people], population density (people $/ \mathrm{km}^{2}$ ) of Warsaw districts and indexes of spatial distribution of water dependent ecosystems, NumP - number of patches, CA - class area, MPS - mean patch size [ha], TE - total edge [km], ED - edge density [km/ha]), abbreviations explained in Patch Analyst Programe manual (Rempel 1999)

\begin{tabular}{|l|r|r|r|r|r|r|r|}
\hline District & $\begin{array}{c}\text { Population } \\
\text { (number of } \\
\text { people) }\end{array}$ & $\begin{array}{c}\text { Density } \\
\text { (people/ } \mathrm{km}^{2} \text { ) }\end{array}$ & NumP & CA & MPS & TE & ED \\
\hline Bemowo & 110331 & 4422.00 & 42 & 589.80 & 14.04 & 129306,17 & 19.13 \\
\hline Białołęka & 84219 & 1153.00 & 384 & 1976.22 & 5.15 & 548660.19 & 81.16 \\
\hline Bielany & 134403 & 4156.00 & 91 & 596.82 & 6.56 & 169816.21 & 25.12 \\
\hline Mokotów & 225730 & 6373.00 & 63 & 316.69 & 5.03 & 90072.63 & 13.32 \\
\hline Ochota & 90549 & 9316.00 & 7 & 18.79 & 2.68 & 5553.64 & 0.82 \\
\hline Praga pn. & 183392 & 8194.00 & 3 & 4.32 & 1.44 & 3171.02 & 0.47 \\
\hline Praga pd. & 72251 & 6327.00 & 26 & 167.81 & 6.45 & 34435.16 & 5.09 \\
\hline Rembertów & 22999 & 1192.00 & 64 & 407.79 & 6.37 & 89909.57 & 13.30 \\
\hline Śródmieście & 130197 & 8362.00 & 15 & 101.82 & 6.79 & 19522.56 & 2.89 \\
\hline Targówek & 122900 & 5074.00 & 85 & 546.75 & 6.43 & 116210.45 & 17.19 \\
\hline Ursus & 49242 & 5261.00 & 4 & 18.53 & 4.63 & 4000.57 & 0.59 \\
\hline Ursynów & 147291 & 3364.00 & 80 & 202.41 & 2.53 & 72156.66 & 10.67 \\
\hline Wawer & 68293 & 857.00 & 138 & 750.65 & 5.44 & 207210.18 & 30.65 \\
\hline Wilanów & 17064 & 465.00 & 93 & 592.44 & 6.37 & 137564.69 & 20.35 \\
\hline Włochy & 39716 & 1387.00 & 61 & 242.82 & 3.98 & 63012.84 & 9.32 \\
\hline Wola & 138919 & 7213.00 & 38 & 214.65 & 5.65 & 50684.83 & 7.50 \\
\hline Żoliborz & 48362 & 5710.00 & 4 & 12.19 & 3.05 & 3800.47 & 0.56 \\
\hline
\end{tabular}


TABLE 2. The effect of population density (peo$\mathrm{ple} / \mathrm{km}^{2}$ ) on water dependent ecosystems fragmentation (* - Sperman's correlation coefficient, significant at $\mathrm{p}<0.05)$

\begin{tabular}{|l|r|l|}
\hline Index & \multicolumn{1}{|c|}{ Mean } & $\mathrm{r}^{2}$ \\
\hline NumP & 70.5 & $-0.793^{*}$ \\
\hline CA & 397.7 & $-0.743^{*}$ \\
\hline MPS & 5.4 & -0.137 \\
\hline TE & 102652.2 & $-0.738^{*}$ \\
\hline ED & 15.2 & $-0.738^{*}$ \\
\hline
\end{tabular}

Urbanization pressure connected with cities expansion leads to degradation of small rivers and wetlands. The process of water dependent habitats disappearance depends on many factors. Population density per area unit seems to be a good indicator of this phenomena. It is worth underlining that green areas within the city, play a key role for wetland preservation. As a result of another investments taking place, often necessary for proper functioning of the city, many

TABLE 3. Selected rare plant species in water dependent habitats of "Zakole Wawerskie" and "Olszyna"; $x$ - recording of species

\begin{tabular}{|l|c|c|c|c|}
\hline \multirow{2}{*}{ Plant Species } & \multicolumn{2}{|c|}{ "Zakole Wawerskie" } & \multicolumn{2}{c|}{ "Olszyna" } \\
\cline { 2 - 5 } & $1987-1991$ & 2008 & 1973 & 2007 \\
\hline Iris sibirica & $\mathrm{x}$ & $\cdot$ & $\cdot$ & $\cdot$ \\
\hline Listera ovata & $\mathrm{x}$ & $\cdot$ & $\cdot$ & $\cdot$ \\
\hline Callitriche cophocarpa & $\mathrm{x}$ & $\mathrm{x}$ & $\cdot$ & $\cdot$ \\
\hline Comarum palustre & $\mathrm{x}$ & $\mathrm{x}$ & $\cdot$ & $\cdot$ \\
\hline Dactyloriza incarnata & $\mathrm{x}$ & $\mathrm{x}$ & $\cdot$ & $\cdot$ \\
\hline Dactylorhiza majalis & $\mathrm{x}$ & $\mathrm{x}$ & $\cdot$ & $\cdot$ \\
\hline Menyanthes trifoliata & $\mathrm{x}$ & $\mathrm{x}$ & $\cdot$ & $\cdot$ \\
\hline Epipactis helleborine & $\mathrm{x}$ & $\mathrm{x}$ & $\cdot$ & $\cdot$ \\
\hline Nuphar lutea & $\mathrm{x}$ & $\mathrm{x}$ & $\cdot$ & $\cdot$ \\
\hline Ophioglossum vulgatum & $\mathrm{x}$ & $\mathrm{x}$ & $\cdot$ & $\cdot$ \\
\hline Parnassia palustris & $\mathrm{x}$ & $\mathrm{x}$ & $\cdot$ & $\cdot$ \\
\hline Pedicularis palustris & $\mathrm{x}$ & $\mathrm{x}$ & $\cdot$ & $\cdot$ \\
\hline Ribes nigrum & $\mathrm{x}$ & $\mathrm{x}$ & $\cdot$ & $\cdot$ \\
\hline Viburnum opulus & $\mathrm{x}$ & $\mathrm{x}$ & $\cdot$ & $\cdot$ \\
\hline Circaea lutetiana & $\mathrm{x}$ & $\mathrm{x}$ & $\cdot$ & $\mathrm{x}$ \\
\hline Impatiens noli-tangere & $\mathrm{x}$ & $\mathrm{x}$ & $\cdot$ & $\mathrm{x}$ \\
\hline Myosotis palustris & $\mathrm{x}$ & $\mathrm{x}$ & $\cdot$ & $\mathrm{x}$ \\
\hline Anemone nemorosa & $\cdot$ & $\cdot$ & $\cdot$ & $\mathrm{x}$ \\
\hline Anemone ranuculoides & $\cdot$ & $\cdot$ & $\cdot$ & $\mathrm{x}$ \\
\hline Dryopteris filix-mas & $\cdot$ & $\cdot$ & $\cdot$ \\
\hline Hedera helix & & $\cdot$ & $\cdot$ \\
\hline
\end{tabular}


decisions are being made which directly or indirectly cause valuable habitats loss. In Warsaw not many works have been made whose purpose was to protect precious ecosystems against negative effects of e.g. road infrastructure. According to the latest trends in ecological sciences it is one of the most important forms of compromise between the needs of the city and protecting natural resources. One of the oldest and at the same time the most interesting example of restoration activities in Warsaw is artificial hydrological system maintaining high water level in "Olszyna". Hygrophilous vegetation of riparian woodlands occurring here, after groundwater level decrease, has been transforming into mesophilic one. Despite the system of reservoirs and ditches designed to keep the water level elevated, maintaining proper functioning of this ecosystems seems to be impossible. Lack of spring flooding causes unfavorable vegetation changes. Increase of total number of species was recorded, which is due to increased number of synanthrophical plants (Sikorska 2008; Sikorska et al. 2009). The case of "Zakole Wawerskie" which is one of the richest in plant species areas in Warsaw $(25 \%$ of all Warsaw taxa occur here (Sudnik-Wójcikowska 1987a, 1987b), indicates that preservation of valuable ecosystem elements is possible, but to be successful requires coordination of work in many fields.

Management of wetlands within urban green areas is a challenge for the future. Vegetation in this areas is very sensitive to trampling (Kostrowicki 1981) and suffer severe pressure because of the recreational use. In places where touristic infrastructure is well prepared, valu- able ecosystems are not being degraded. Such places should be well marked and should allow visiting and observing for tourist in a way that does not cause any damage.

\section{CONCLUSIONS}

- In the centre of Warsaw water dependent habitats remained mainly within green areas.

- Natural water dependent ecosystems in urban areas are suffering from constant long-term changes whose strength and direction are hard to predict, especially when the water regime had been changed.

- Results of these changes can usually be assessed after tens of years.

- Regulations of the water outflow and as a result temporal drainage led to changing of the vegetation associated with wetlands vegetation into more mesophilic one.

- Facilities within cities given to people, such as „Olszyna” Complex, are subjected to additional threats of damaging the vegetation that is being adapted to new conditions. Temporarily drier objects are becoming more accessible at not sufficient communication infrastructure.

- Urbanization pressure is indirectly connected with population density per area unit.

\section{REFERENCES}

BALDWIN A.H. 2004: Restoring complex vegetation in urban settings: The case of freshwater tidal marshes. Urban Ecosyst. 7, 125-137. 
EHRENFELD J.G. 2000: Evaluation of wetlands within an urban context. Urban Ecosyst. 4, 69-85.

GAUTHIER P., DEBUSSCHE M., THOMPSON J.D. 2010: Regional priority setting for rare species based on a method combining three criteria. Biol. Conserv. 143, 1501-1509.

ELLENBERG H., WEBER H., DÜLL R., WIRTH V., WERNER W., PAULISSEN D. 1991: Zeigerwerte der Gefäßpflanzen in Mitteleuropas. Scripta Geobot. 18, $1-166$.

GRIME N.B., GROVE J.M., PICKETT S.T.A., REDMAN C.L. 2000: Integrated approaches to long-term studies of urban ecological systems. BioScience 50, 571-584.

KLOSS M. 2001: Naturalność i zgodność $\mathrm{z}$ biotopem nieleśnych fitocenoz bagiennych na niżu Polskim [Naturalness and biotop compatibility of wet woodland phytocenoses], [in:] Zielony R. [eds.] Zgodność fitocenozy $z$ biotopem w ekosystemach leśnych. Wyd. Fundacja „Rozwój SGGW". Warszawa: 121-136.

KŁOSOWSKI S. 2009: Ochrona gatunkowa. Rośliny [Species preservation. Plants], [in:] Wojtatowicz J. [eds.]. Przyroda Warszawy. TMS Media. Warszawa, 197-199.

KOSTROWICKI A.S. 1981: Metoda określania odporności roślin na uszkodzenia mechaniczne na skutek wydeptywania [Methods of assessing plants resistance to mechanical damage caused by trampling] In: Kostrowicki A.S. [eds.]. Wybrane zagadnienia teorii i metod oddziaływania człowieka na środowisko. Wyd. PAN. Wrocław-Kraków-Gdańsk, 39-70 [Engl. summ.].

McDONNELL M.J., PICKETT S.T.A., GROFFMAN P., BOHLEN P., POUYAT R.V., ZIPPERER W.C., PARMELEE R.W., CARREIRO M.M., MEDLEY K. 1997: Ecosystem processes along an urban-to-rural gradient. Urban Ecosyst. 1, 21-36.
McGARIGAL K., MARKS B.J. 1994: FragStats: Spatial Pattern Analysis Program for Quantifying Landscape Structure (version 2.0). Forest Science Department, Oregon State University. Corvallis.

McKINNEY M.L. 2002: Urbanization, biodiversity and conservation. Bioscience 52, 883-890.

PAJNOWSKA H., JEZNACH J., SIERADZ A. 1996: Ekspertyza przyrodnicza dotycząca metody ochrony Zespołu Przyrodniczo-Krajobrazowego "Olszyna". [Ecological survey on methods for protection of Natural Landscape Complex „Olszyna"]. Maszynopis. Katedra Kształtowania Środowiska SGGW w Warszawie.

PAWLAK J., KALISZUK E. 2006: Gleby [Soils]. [in:] Teisseyre-Sierpińska M., Pawlak J. [eds.], 2006, Opracowanie ekofizjograficzne do studium uwarunkowania i kierunków zagospodarowania przestrzennego m.st. Warszawy. Urząd Miasta Stołecznego Warszawy, 46-47.

ANONYMOUS 2002: Opracowanie ekofizjograficzne dla studium uwarunkowań i kierunków zagospodarowania przestrzennego. Urząd Miasta StołecznegoWarszawy. [http://um.warszawa.pl/wydarzenia/ekofizjografia/1.php]

REMPEL R. 1999: Patch Analyst - user's manual. NWST Technical manual TM002: Centre for Northern Forest Ecosystem Research. Ontario [www.uni-klu. ac.at/geo/lv_online/seminar2002/pa manual.pdf]

ROO-ZIELIŃSKA E., SOLON J., DEGÓRSKI M. 2007: Ocena stanu i przekształceń środowiska przyrodniczego na podstawie wskaźników geobotanicznych, glebowych i krajobrazowych. [Assessment of condition and changes in environment on the basis of geobotanical, landscape and soil indices]. Wyd. IGiPZ. Warszawa [Engl. summ.].

SIKORSKA D. 2008: Zmiany siedliskowe w Zespole Przyrodniczo-Krajobrazowym „Olszyna” i ich wpływ na roślinność. [Habitat changes in Natural Landscape Complex "Olszyna" and their effect on 
vegetation]. Maszynopis. Międzywydziałowe Studium Ochrony Środowiska SGGW: 1-69 [Engl. summ.].

SIKORSKA D., SIKORSKI P., HEWELKE P. 2009: Duration of vegetation disturbance in urban hydrogenic ecosystems due to drainage, Ann. Warsaw Agricul. Univ. - SGGW, Hortic. Landsc. Architect. 30, 207-215.

SUDNIK-WÓJCIKOWSKA B. 1987a: Flora of Warsaw and its changes in the 19-th and 20-th century. Part 1. (in Polish). Wyd. Uniw. Warsz., Warszawa, 1-242 [Engl. summ.].

SUDNIK-WÓJCIKOWSKA B. 1987b: Flora of Warsaw and its changes in the 19th and 20th century. Part 2. (in Polish). Wyd. Uniw. Warsz., Warszawa, 1-436.

SUKOPP H. 1998: Urban ecology: scientific and practical aspects, [in:] BREUSTE J., FELDMANN H., UHLMANN O. [Eds.]. Urban Ecology. Springer-Verlag, Berlin, 3-16.

SYMONIDES E., SOLIŃSKA-GÓRNICKA B. 1990: Funkcjonowanie reliktów naturalnych zadrzewień środowisku zurbanizowanym (Functioning of relicts of natural woodland vegetation in Urban environment) [in:] Zimny H., Funkcjonowanie układów ekologicznych w środowisku zurbanizowanym. Wyd. SGGW, 168-184 [Engl. summ.].

WYSOCKI C. 1973: Ekspertyza ekologiczna terenu zadrzewienia olszowego $\mathrm{w}$ granicach ulic Broniewskiego-WłościańskiejDuracza. [Ecological expertise on alder woodland in the area between the streets: Broniewskiego-Włościańskiej-Duracza] Maszynopis. Katedry Ochrony Środowiska SGGW. Warszawa. 1-3 + phytosociological tables.

Streszczenie: Ochrona ekosystemów hydrogenicznych na terenach zurbanizowanych. Ekosystemy hydrogeniczne ze względu na swoją silną zależność od warunków hydrologicznych należą do najbardziej wrażliwych na presję urbanizacyjna. W Warszawie niewiele jest takich obiektów, a te, które przetrwały, są to najczęściej odwodnione siedliska znajdujące się na terenach parków miejskich i zieleńców. Ekosystemy związane z glebami torfowymi i murszowymi charakteryzuja się wysoka wartościa przyrodnicza, istnieje więc potrzeba ich wnikliwego badania oraz wyceny, aby efektywnie chronić te cenne obszary. Niniejsza praca stanowi studium dwóch przypadków ekosystemów hydrogenicznych, znajdujących się w granicach Warszawy i podlegających silnej presji urbanizacyjnej. Zostały podjęte różne działania, by przeciwdziałać negatywnym procesom zachodzących $\mathrm{w}$ tych obiektach, $\mathrm{z}$ odmiennym skutkiem. Na podstawie danych florystycznych badano tendencje zmian roślinności w ostatnich 20-30 latach. W obszarach, gdzie zaburzony został reżim hydrologiczny, jak na przykład Zespół Przyrodniczo-Krajobrazowy „Olszyna”, zanotowano spadek udziału gatunków roślin rzadkich w skali Warszawy. W siedliskach niedotkniętych silnie przez antropopresję, jak Zakole Wawerskie, nie zanotowano istotnych zmian w składzie gatunkowym, stwierdzono natomiast zwiększenie się liczby gatunków rzadkich w skali Warszawy. Zauważono również pośredni wpływ gęstości zaludnienia na siedliska hydrogeniczne - w obszarach najsilniej zaludnionych występują one najrzadziej, charakteryzują się też niewielkim rozmiarem i uproszczona linią brzegową. Obszarami, w których ten typ ekosystemów przetrwał w przestrzeni Warszawy, są jedynie parki miejskie. W ostatnich latach obserwuje się zanikanie mokradeł, co zostało również przedstawione w niniejszym studium. Szansę na podtrzymanie istnienia ekosystemów hydrogenicznych upatruje się w tworzeniu tzw. ostoi różnorodności biologicznej oraz dobrze przygotowanej infrastruktury turystycznej.

Stowa kluczowe: ekosystemy hydrogeniczne, urbanizacja, zmiany roślinności, obszary chronione.

MS. received November 15, 2010
Author's address:
Daria Sikorska
Katedra Kształtowania Środowiska
SGGW
ul. Nowoursynowska 159
02-787 Warszawa
Poland
daria_sikorska@sggw.pl 